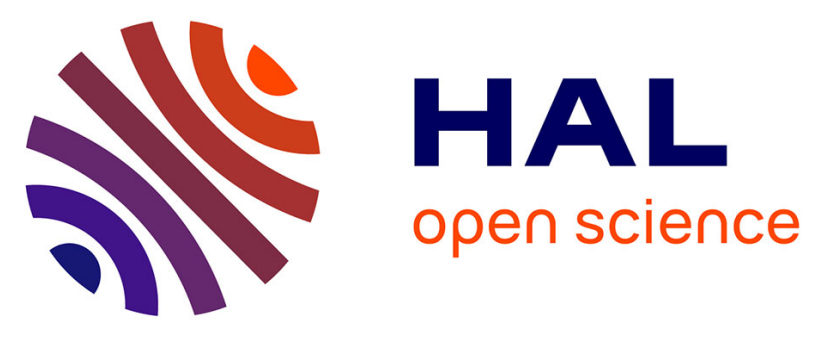

\title{
Accumulation, speciation and localization of silver nanoparticles in the earthworm Eisenia fetida
}

Pauline Courtois, Agnieszka Rorat, Sébastien Lemiere, Clément Levard, Perrine Chaurand, Anna Grobelak, Christine Lors, Franck Vandenbulcke

\section{To cite this version:}

Pauline Courtois, Agnieszka Rorat, Sébastien Lemiere, Clément Levard, Perrine Chaurand, et al.. Accumulation, speciation and localization of silver nanoparticles in the earthworm Eisenia fetida. Environmental Science and Pollution Research, 2020, 10.1007/s11356-020-08548-z . hal-02551889

\section{HAL Id: hal-02551889 \\ https://hal-amu.archives-ouvertes.fr/hal-02551889}

Submitted on 23 Apr 2020

HAL is a multi-disciplinary open access archive for the deposit and dissemination of scientific research documents, whether they are published or not. The documents may come from teaching and research institutions in France or abroad, or from public or private research centers.
L'archive ouverte pluridisciplinaire HAL, est destinée au dépôt et à la diffusion de documents scientifiques de niveau recherche, publiés ou non, émanant des établissements d'enseignement et de recherche français ou étrangers, des laboratoires publics ou privés. 
Pauline Courtois ${ }^{1}$, Agnieszka Rorat ${ }^{1}$, Sébastien Lemiere ${ }^{1}$, Clément Levard ${ }^{2}$, Perrine Chaurand ${ }^{2}$, Anna

4 Grobelak $^{3}$, Christine Lors ${ }^{1}$ and Franck Vandenbulcke ${ }^{1 *}$

5

$6{ }^{1}$ Univ. Lille, IMT Lille Douai, Univ. Artois, Yncrea Hauts-de-France, ULR 4515, - LGCgE, Laboratoire de 7 Génie Civil et géo-Environnement, F-59000 Lille, France

$8 \quad{ }^{2}$ Aix Marseille Univ, CNRS, IRD, INRAE, Coll France, CEREGE, Aix-en-Provence, France

$9{ }^{3}$ Institute of Environmental Engineering, Faculty of Infrastructure and Environment, Czestochowa University of

Technology, Czestochowa, Poland

11

*Address correspondence to: Franck Vandenbulcke

e-mail: franck.vandenbulcke@univ-lille.fr

Université de Lille, Sciences et Technologies

Laboratoire de Génie Civil et géo-Environnement, LGCgE EA4515

Cité Scientifique, Bât. SN3 - F-59655 Villeneuve d’Ascq

The authors wish to thank Dominique Dubois, Olivier Proux, Géraldine Sarret, Ana Elena Pradas Del Real, Kerstin Hund-Rinke and Régine Leroux for their help and fruitful discussions.

\section{Funding}

This study was funded mainly by the ANSES in the ETNA2 project context, by a grant of the University of Lille and the SMRE doctoral school and by a public grant overseen by the French National Research Agency (ANR) as part of the French platform NanoID (EQUIPEX project ANR-10-EQPX-39-01). 

computed tomography

\section{Keywords}

The use of silver nanoparticles (AgNPs) in agriculture and many consumer products has led to significant release of $\mathrm{Ag}$ in the environment. Although $\mathrm{Ag}$ toxicity in terrestrial organisms has been studied extensively, very little is known about the accumulation capacity and coping mechanisms of organisms in Agcontaminated soil. In this context, we exposed Eisenia fetida earthworms to artificial OECD soil spiked with a range of concentrations of $\mathrm{Ag}\left(\mathrm{AgNPs}\right.$ or $\left.\mathrm{AgNO}_{3}\right)$. The main aims were to (1) identify the location and form of accumulation of $\mathrm{Ag}$ in the exposed earthworms and (2) better understand the physiological mechanisms involved in $\mathrm{Ag}$ detoxification. The results showed that similar doses of $\mathrm{AgNPs}$ or $\mathrm{AgNO}_{3}$ did not have the same effect on E. fetida survival. The two forms of Ag added to soil exhibited substantial differences in speciation at the end of exposure, but the $\mathrm{Ag}$ speciation and content of $\mathrm{Ag}$ in earthworms were similar, suggesting that biotransformation of $\mathrm{Ag}$ occurred. Finally, 3D images of intact earthworms obtained by X-ray micro-computed tomography revealed that Ag accumulated preferentially in the chloragogen tissue, coelomocytes and nephridial epithelium. Thus, E. fetida bioaccumulates Ag, but a regulation mechanism limit its impact in a very efficient manner. The location of $\mathrm{Ag}$ in the organism, the competition between $\mathrm{Ag}$ and $\mathrm{Cu}$, and the speciation of internal $\mathrm{Ag}$ suggest a link between $\mathrm{Ag}$ and the thiol-rich proteins that are widely present in these tissues, most probably metallothioneins, which are key proteins in the sequestration and detoxification of metals.

Silver, nanomaterials, earthworm, accumulation, speciation, X-ray absorption spectroscopy, X-ray micro- 


\section{INTRODUCTION}

Due to advances in nanotechnology and the increasing use of nanomaterials, metallic silver nanoparticles (AgNPs) are an emerging contaminant in the terrestrial environment (McGillicuddy et al., 2017). The incorporation of AgNPs in consumer products is increasing due to their unique properties, particularly their antimicrobial effects (Vance et al., 2015). Most silver (Ag) release occurs in municipal wastewater, and wastewater treatment plants allow efficient sequestration of $\mathrm{Ag}$ in sewage sludge (Kaegi et al., 2011). However, the Ag species trapped in these biosolids are subsequently spread on agricultural soil when sludge is recycled as fertilizer (Usman et al., 2012). A number of studies have shown that metallic Ag is transformed mostly into silver sulfide (Kaegi et al., 2013; Ma et al., 2014) and silver bound to thiols in the sewage system. This transformation strongly affects the behavior of Ag in the environment (Levard et al., 2012; Pradas del Real et al., 2017).

Another potential environmental exposure scenario in terrestrial ecosystems is the use of $\mathrm{Ag}$ as a nanopesticide or nanofertilizer via the direct application of metallic $\mathrm{Ag}$ to agricultural soils. Ag has bactericidal, fungicidal, insecticidal and herbicidal properties, and AgNPs have high inhibitory activity against crop pathogens (Chhipa, 2019; Khan and Rizvi, 2017). Moreover, AgNPs positively impact root elongation and the general growth of cultivated plants (Chhipa, 2019) when applied at concentrations between 1 and 200 ppm, depending on the plant species. However, at these concentrations, AgNPs are toxic to a variety of organisms.

The toxicological effects of AgNPs are quite well documented and include numerous impacts on soil microflora, flora and soil invertebrates (Courtois et al., 2019). The potential transfer of Ag in plants has received more attention (Yan and Chen, 2019) than transfer of Ag in animals. Most studies in animals have focused on life traits and protein changes in exposed animals (Yu et al., 2013). Although accumulation of Ag could be an important vector of the transfer of this metal in the trophic chain, studies of the underlying mechanisms are scarce.

In soil ecotoxicology, earthworms are widely studied based on their key role in most continental ecosystems and importance in the soil macrofauna. Earthworms participate in the maintenance of soil structure and fertility. In addition to enriching the soil with organic matter available for plants, they aerate the soil and promote water penetration by forming galleries during their burrowing activity (Bernard et al., 2010; Carbonell et al., 2009). Earthworms are highly consumed by birds, snakes, insectivorous mammals and rodents, especially during tillage. Consequently, accumulated contaminants can quickly move to upper trophic levels. 

and speciation. In the present study, we investigated the accumulation, localization, and speciation of $\mathrm{Ag}$ (presented as NM-300K AgNPs or $\mathrm{AgNO}_{3}$ ) in earthworms using several X-ray techniques. The main objective was to better understand how earthworms cope with $\mathrm{Ag}$ soil contamination in the context of silver pesticide/fertilizer use. For this purpose, Eisenia fetida earthworms were exposed to artificial OECD soil contaminated with a range of $\mathrm{AgNP}$ concentrations for 4 weeks. The effect of ionic $\mathrm{Ag}\left(\mathrm{AgNO}_{3}\right)$ was investigated as a positive control. Biomass and mortality were followed, and $\mathrm{Ag}$ accumulation, speciation and localization in earthworms were measured. Finally, the accumulation mechanisms are discussed.

\section{MATERIALS AND METHODS}

\subsection{Test species}

Genetically identified Eisenia fetida earthworms (Homa et al., 2015) from the laboratory breeding facility (LGCgE, University of Lille) were fed cow manure ad libitum. Adult earthworms, clitellated or not, were randomly selected and introduced into the microcosms after being weighed individually. The earthworms weighed $296 \mathrm{mg}$ on average (min: $104 \mathrm{mg}$, max: $751 \mathrm{mg}$, mean standard deviation: $95 \mathrm{mg}$ ).

\subsection{Soil}

Artificial soil was prepared for this experiment according to OECD guideline $\mathrm{n}^{\circ} 207$ (OECD, 1984) and contained 10\% sphagnum peat moss, $20 \%$ kaolin clay and $70 \%$ quartz sand. The soil $\mathrm{pH}$ was adjusted with calcium carbonate to $6 \pm 0.5$. Five weeks before adding the contaminant, $16.5 \mathrm{~kg}$ of soil was moistened with 6 liters of demineralized water. When the earthworms were added to the soil, water represented $27 \%$ of the weight of the wet soil.

\subsection{Silver species}

The standard reference material Ag-NM300K from the European Commission Joint Research Centre (JRC) was used as the AgNP source and was fully characterized in a previous work (Klein et al., 2011). Commercial NM300K-NPs were kindly provided by the Fraunhofer Institute for Molecular Biology and Applied Ecology IME. Each bottle contained $2 \mathrm{~g}$ of NM300K diluted in dispersant with a volume of $2 \mathrm{~mL}$. These metallic nanoparticles (NPs) were spherical and not coated and were dispersed in polyoxyethylene glycerol trioleate and polyoxyethylene sorbitan mono-laurate (dispersant) with a nominal silver content of $10.2 \%$ by 
weight. Ninety-nine percent of the particles had a nominal size below $20 \mathrm{~nm}$. Transmission electron microscopy indicated a mean size of $17 \pm 8 \mathrm{~nm}$. Smaller NPs of approximately $5 \mathrm{~nm}$ were also present (Mendes et al., 2015). $\mathrm{AgNO}_{3}$ solution was also prepared for comparison with exposure to $\mathrm{Ag}$ in ionic form. Silver nitrate salt $\left(\mathrm{AgNO}_{3}\right)$ was dissolved in sterile distilled water. The AgNPs and $\mathrm{AgNO}_{3}$ solution were diluted with ultrapure water to obtain a final $\mathrm{Ag}$ concentration of $2 \mathrm{mg} \mathrm{mL}^{-1}$.

\subsection{Experimental scheme (earthworm exposure)}

Earthworms in microcosms (with OECD artificial soil) were exposed to a range of Ag forms and concentrations. Four types of soil mixtures corresponding to 2 controls and 2 exposed conditions were prepared: control (soil only), dispersant (soil spiked with dispersant solution), AgNPs (soil spiked with AgNP solution) and $\mathrm{AgNO}_{3}$ (soil spiked with $\mathrm{AgNO}_{3}$ solution) (see Sup. Inf 1). Four different $\mathrm{Ag}$ concentrations, C1, C2, C3 and C4, were used for the AgNP and $\mathrm{AgNO}_{3}$ microcosms: $30( \pm 20), 70( \pm 10), 120( \pm 15)$ and $280( \pm 40) \mathrm{mg} \mathrm{kg}^{-1}$ (dry matter), respectively (these concentrations were chosen based on mortality rates reported in Garcia-Velasco et al. (2016) and Gomes et al. (2015)). Four different volumes of NM300K dispersant were used in the dispersant microcosms, which served as controls. These volumes were named D1, D2, D3 and D4 and corresponded to the dispersant volumes added in the AgNP microcosms for $\mathrm{C} 1, \mathrm{C} 2, \mathrm{C} 3$ and $\mathrm{C} 4$, respectively. Thus, a total of 13 microcosm conditions were established in triplicate. Ten earthworms were introduced in each microcosm, with a total of 390 earthworms. The exposure lasted 4 weeks. No food was added to the initial soil or during exposure.

\subsection{Analyses}

Life traits. Survival and biomass were measured. Biomass was followed by comparing the masses of the groups of organisms before and after exposure, and the results were expressed as the percentage loss.

Metal concentrations in soils and accumulation in earthworms. Immediately before exposure (T0), unexposed earthworms from the breeding facility were sacrificed to measure the metal concentrations present in the organisms. After exposure, earthworms were collected from each microcosm and placed in $1 \%$ agar for 24 hours for depuration (i.e. to remove the gut content). Then, the earthworms were sacrificed by freezing for at least 48 hours and freeze-dried. The organisms were reduced to powder using liquid nitrogen and mineralized by digestion in acid medium (using $\mathrm{HNO}_{3}, \mathrm{H}_{2} \mathrm{SO}_{4}$ and $\mathrm{HCl}_{4}$ in a ratio of 10:2:3) as described by Bernard et al. (2010). 
Soil samples were collected at the beginning ( $\mathrm{T} 0)$ and at the end of exposure ( $\mathrm{Tf}=4$ weeks). These samples were freeze-dried and ground with a mortar and a pestle. For mineralization, $300 \mathrm{mg}$ of sample was digested in $7 \mathrm{~mL}$ of concentrated $\mathrm{HNO}_{3}$ using a Berghof microwave digestion system (speed wave MWS-2 microwave pressure digestion). The solutions obtained (mineralized earthworms and soils) were analyzed by ICP-OES (inductively coupled plasma-optical emission spectrometry) (Varian 720-ES, USA). The following classically studied metals were quantified: arsenic $(\mathrm{As})$, chromium $(\mathrm{Cr})$, cadmium $(\mathrm{Cd})$, copper $(\mathrm{Cu})$, nickel $(\mathrm{Ni})$, lead $(\mathrm{Pb})$, zinc $(\mathrm{Zn})$ and Ag.

\section{Localization of silver in exposed earthworms using X-ray $3 D$ imaging}

Two earthworms were imaged in 3D using X-ray micro-computed tomography (micro-CT): one non-exposed sample and one sample exposed to AgNPs (AgNP-C3) collected after 4 weeks in the dispersant and AgNP microcosms, respectively.

Sample preparation. After 24 hours of depuration in $1 \%$ agar, the earthworms were first anesthetized on ice and fixed for 16 hours in ice-cold $4 \%$ paraformaldehyde in $0.1 \mathrm{M}$ phosphate buffer. They were then dehydrated by soaking in a graded series of ethanol solutions (from 30\% vol to 100\% vol.) and subjected to supercritical point drying (Leica EM $\mathrm{CPD} 300^{\circ}$ ). In this drying process, ethanol is replaced with liquid $\mathrm{CO}_{2}$, which avoids the creation of damaging surface tension forces associated with drying by bringing the liquid in the sample to the gas phase without crossing the liquid-gas phase boundary. The dried samples were finally placed in polyimide tubing (Kapton).

$3 D$ image acquisition. 3D imaging of the earthworms was performed with a microXCT-400 X-ray microscope (Zeiss). High-resolution scans were acquired at $40 \mathrm{kV}$ and $250 \mu \mathrm{A}$. A total of 2501 projections were collected through $360^{\circ}$ rotation with an exposure time of $20 \mathrm{~s}$ per projection. A 20x magnification optical objective was selected to achieved an isotropic voxel of $0.9 \mu \mathrm{m}$ and a field-of-view (FOV) of $0.9 \times 0.9 \times 0.9 \mathrm{~mm}^{3}$. The FOV was centered at the lower end of the earthworm (rings 9 and 10 for the control and exposed earthworms, respectively) and included the coelomic cavity and the nephridia epithelium. The position of the FOV was selected from previsualization scans of the entire earthworm with lower spatial resolution (Supporting information 2). Volume reconstruction was performed with XMReconstructed-Parallel Beam-9.0.6445 software using a filtered back projection algorithm.

$3 D$ image analysis. Avizo 8.0 software (Hillsboro, OR, USA) was used for the visualization, processing, and analysis of the reconstructed dataset. The procedure developed in Chaurand et al. (2018) to isolate metal-based 
NPs was followed. Briefly, images of exposed and non-exposed (control) samples were compared after

173 histogram $\mathrm{x}$-axis normalization (i.e. colormap normalization). The histogram represents the X-ray attenuation in each voxel (expressed as an arbitrary gray scale value, GSV) of the analyzed volume as a function of the number of voxels for each GSV (intensity). The histogram x-axis was normalized using air as an internal standard. After the normalization step, the brilliant voxels in the image of the exposed sample that were not identified in the image of the control sample were attributed to the presence of Ag by thresholding (Supporting information 3).

Speciation of silver in soils and earthworms. Silver speciation in soil and earthworms was determined by X-ray absorption near-edge structure (XANES) spectroscopy, which permits the determination of the local atomic environment (speciation) of targeted atoms present in complex media. Silver K-edge (25.51 keV) XANES spectra were acquired at the European Synchrotron Radiation Facility (ESRF, France) on the FAME beamline (BM30b) with Si(220) monochromator crystals (Proux et al., 2005). Prior to analysis, the earthworm samples were lyophilized, ground and pressed into 5-mm pellets. Spectral acquisition was performed at liquid helium temperature to avoid sample evolution under the beam. Measurements were carried out in fluorescence mode using a 30-element Canberra Ge solid-state detector. Each spectrum was the sum of at least three scans. A set of model compounds including metallic $\mathrm{AgNPs}, \mathrm{AgNO}_{3}, \mathrm{Ag}_{2} \mathrm{~S}, \mathrm{AgCl}, \mathrm{Ag}$-thiocarbamate (Ag-thio), and $\mathrm{Ag}$ humic acid (Ag-HA) was run in transmission mode. Normalization data reduction and linear combination fitting (LCF) were performed according to standard methods using Athena software (Ravel and Newville, 2005). The residual factor of LCF was calculated according to the formula $\mathrm{R}=\sum\left(\exp -\mathrm{fit}^{2} / \sum(\mathrm{exp})^{2}\right.$, where the sums are over the data points in the fitting region. At each step of the fitting, an additional reference spectrum was added if the following two conditions were true: the $\mathrm{R}$ factor decreased by $20 \%$ or more and the additional reference had a contribution equal to or higher than $10 \%$ among Ag species.

\subsection{Statistical analysis}

For biomass, mortality and metal content in earthworms, the majority of the data did not follow a normal distribution, and the variances were not homogeneous (Shapiro, Liliefors and Bartlett tests). Thus, Sheirer-Ray-Hare non-parametric tests and post-hoc tests based on ranks were used. For data following a normal distribution with homogeneous variances, ANOVA tests and Tuckey post-hoc tests were used. Correlation matrices (based on the Kendall method) were constructed. Tests were performed using the R package (R Core Team, 2018). 


\section{RESULTS}

Metal quantities in soil. At the initial time point, the concentrations of $\mathrm{As}, \mathrm{Cr}, \mathrm{Cu}, \mathrm{Ni}, \mathrm{Pb}$ and $\mathrm{Zn}$ were 1.08 (standard deviation 0.34), 1.05 (s.d. 0.30), 5.31 (s.d. 1.22), 0.62 (s.d. 0.38), 10.13 (s.d. 2.11) and 5.16 (s.d. 0.66) $\mathrm{mg} \mathrm{kg}^{-1}$, respectively. The concentration of $\mathrm{Cd}$ was below the detection limit. The Ag concentrations in the microcosms are shown in Table 1. As expected, there was no significant difference in $\mathrm{Ag}$ doses between the $\mathrm{AgNP}$ and $\mathrm{AgNO}_{3}$ microcosms at each concentration $(\mathrm{C} 1, \mathrm{C} 2, \mathrm{C} 3$ and $\mathrm{C} 4)$. Only very low concentrations of $\mathrm{Ag}$ were detected in the control and dispersant microcosms. One control microcosm appeared to have been very slightly contaminated by accident, but its Ag concentration remained negligible compared with the exposure conditions.

The concentrations of other metals were very low compared with Ag, which suggests that these metals would not hinder the accumulation of Ag by earthworms.

Life traits. A survival rate of $100 \%$ was observed in all of the control, dispersant and AgNP microcosms (Fig. 1). In the $\mathrm{AgNO}_{3}$ microcosms, dose-dependent mortality was observed, with $6.7 \%$ mortality at the lowest concentration and $100 \%$ mortality at the highest concentration. During the 4 weeks of exposure, the earthworms lost weight in all microcosms, including the controls. Thus, the loss of weight cannot be linked to $\mathrm{Ag}$ contamination. Biomass data for earthworms in the $\mathrm{AgNO}_{3}-\mathrm{C} 4$ microcosm are absent due to total mortality.

Metals bioaccumulation: silver. At the end of exposure, the Ag content in earthworms varied among the different treatments (Fig. 2). Silver was not detected in organisms in the control microcosms. In the presence of $\mathrm{Ag}$, earthworms accumulated between 2.8 and $9.9 \mathrm{mg} \mathrm{kg}^{-1}$ (average $5 \mathrm{mg} \mathrm{kg}^{-1}$ of dry matter). The accumulation of $\mathrm{Ag}$ in the earthworms exposed to $\mathrm{Ag}$ was independent of the form of $\mathrm{Ag}$ (NPs or ionic) or the $\mathrm{Ag}$ dose in the microcosm. Data for earthworms in the AgNO3-C3 and AgNO3-C4 microcosms are absent because the insufficient quantity of material available for analysis due to significant mortality. were observed for $\mathrm{Cd}, \mathrm{Cr}, \mathrm{Ni}, \mathrm{Pb}$ and $\mathrm{Zn}$ compared with the corresponding control. A single significant difference in As concentration was observed between the $\mathrm{AgNO}_{3}-\mathrm{C} 2$ microcosm and its control (Supporting information 2). The $\mathrm{Cu}$ concentration in earthworms was similar in all treatments without Ag (Fig. 3). In the 
$\mathrm{AgNO}_{3}-\mathrm{C} 2$ microcosm (no results were obtained for the $\mathrm{AgNO}_{3}-\mathrm{C} 3$ and $\mathrm{AgNO}_{3}-\mathrm{C} 4$ microcosms because of earthworm mortality), there was a decrease in the $\mathrm{Cu}$ concentration, but this difference was not significant compared with the control. However, in the AgNP microcosms, earthworms accumulated significantly less $\mathrm{Cu}$ (approximately two times less) compared with the controls.

In summary, $\mathrm{Ag}$ was the only metal present in greater concentrations in earthworms exposed to AgNPs conditions than in those under control conditions.

Localization of Ag in earthworms: Brilliant voxels (i.e. voxels exhibiting high X-ray absorption) were observed in the micro-CT volume of exposed earthworms (AgNP-C3, with $109.57( \pm 8.05) \mathrm{mg} \mathrm{kg}^{-1}$ of AgNPs). Although this imaging technique cannot identify the source of these brilliant voxels, they were not observed in the non-exposed earthworm volume (Dis-D3, in dispersant) and can therefore be attributed to Ag accumulation areas by thresholding (Fig. 4) due to the absence of differences in bioaccumulation for other elements with high densities (metals). Thresholding provides the distribution of these areas of brilliant voxels (colored in red) in the whole scanned volume. Ag accumulation areas/spots were observed around the digestive tract, in the coelomic cavity, in free cells in the coelomic cavity (coelomocytes) and in the nephridial epithelium (Fig. 4).

Speciation of silver. Ag speciation in OECD soil after 4 weeks of incubation depended on the initial form (NPs or ionic). Ag initially spiked as AgNPs remained mainly metallic, but approximately $15 \%$ became complexed with natural organic thiols (Fig. 5). Ag initially spiked as $\mathrm{AgNO}_{3}$ was linked with humic acid (52\%) and organic thiols (33\%), and approximately $15 \%$ was in metallic form. Regardless of the exposure scenario ( $\mathrm{AgNPs}$ or $\mathrm{AgNO}_{3}$ ), the speciation of $\mathrm{Ag}$ accumulated in earthworms was similar and consisted of $\mathrm{Ag}$ bound to thiols (Fig. 5).

\section{DISCUSSION}

OECD soil is a simplified matrix for evaluating the effects of medium- and long-term exposure in a soil naturally deprived of many metals and other contaminants. In the present study, the use of OECD soil allowed the effects of added Ag and the underlying mechanisms to be explored under simplified experimental conditions. To prevent the possible ingestion of additional metals, no food was added to the medium. Use of this medium 
was therefore appropriate for the main objective of our work, which was to locate the sites of Ag accumulation by micro-CT.

High AgNP concentrations did not affect the life traits of E. fetida earthworms. The weight loss observed in the AgNPs microcosms was similar to that observed under control conditions and was due to a lack of food. OECD soil is poor in organic matter and nutrients, and food was not provided during the experiment. By contrast, dose-dependent toxicity of $\mathrm{AgNO}_{3}$ resulting in weight loss and mortality was observed. Thus, the toxicity of $\mathrm{Ag}^{+}$was stronger than that of AgNPs, consistent with previous observations of E. fetida in both artificial (Diez-Ortiz et al., 2015a; Gomes et al., 2015; Heckmann et al., 2011) and natural soils (Novo et al., 2015). Higher toxicity of ionic Ag compared with AgNPs has been reported for many plants and animal species (Courtois et al., 2019), and there is a consensus that the toxicity of $\mathrm{Ag}$ is mainly due to its ionic form. We recognize that the starvation of the earthworms may have interfered with the results presented here. In the presence of optimal food, the effects of the two forms of Ag might be exacerbated or reduced.

Despite the differences in toxicity observed between the treatments, in all conditions with Ag (ionic or NPs), the mean bioaccumulation by earthworms in the body was 4 to $5 \mathrm{mg} \mathrm{kg}^{-1}$ (dry matter). Thus, the form of $\mathrm{Ag}$ (NPs or ionic) had no influence on the amount of Ag bioaccumulation. In earthworms, metal accumulation is related not only to food intake but also to dermal absorption of dissolved ions (Vijver et al., 2003). Because of the differences in Ag speciation in soil, one might expect Ag linked to organic matter (humic acids) to be metabolized more readily than thiolated $\mathrm{Ag}$. When combined with the dermal absorption of $\mathrm{Ag}^{+}$ions, this increased metabolism could explain the higher toxicity of $\mathrm{AgNO}_{3}$. However, (Diez-Ortiz et al., 2015b; GarciaVelasco et al., 2016) showed that Ag is mainly internalized by soil ingestion. Our bioaccumulation results show that $\mathrm{Ag}$ can enter the earthworm body. Ag may also pass though the epidermis as dissolved $\mathrm{Ag}^{+}$ions. Unrine et al. (2008) demonstrated that dermal absorption of $\mathrm{Au}$ nanoparticles occurs in earthworms. However, as mentioned previously, dermal absorption is not the main route of metal internalization.

Contradictory results were reported by Shoults-Wilson et al. (2010) and Bourdineaud et al. (2019), who showed that E. fetida in artificial soil accumulated two to fifteen times more silver when exposed to $\mathrm{AgNO}_{3}$ compared with AgNPs. Interestingly, these authors used AgNPs that were two to three times larger (between 50 and $60 \mathrm{~nm}$ ) than the NM-300K AgNPs used in this study, which may have hindered the dermal absorption and metabolism of AgNPs. Supporting this hypothesis, Unrine et al. (2008) showed that the internalization of metallic NPs (Zn and Au) in E. fetida decreased with increasing NP size. 
The Ag concentration in the soil did not influence Ag bioaccumulation by earthworms, which suggests that a very efficient regulation mechanism limits the internal content of $\mathrm{Ag}$ even when the environmental concentration is very high. A similar phenomenon (plateau and regulation) was reported by Coutris et al. (2011), who observed rapid $\mathrm{Ag}$ excretion from E. fetida after the end of exposure.

Regardless of the original form of $\mathrm{Ag}$ in the microcosms, the bioaccumulated $\mathrm{Ag}$ in earthworms was always bound to organic thiols. However, in OECD soil, even after 4 weeks of incubation, Ag speciation differed greatly between the $\mathrm{AgNP}$ and $\mathrm{AgNO}_{3}$ microcosms, indicating biotransformation of $\mathrm{Ag}$ by earthworms. Since a regulation/excretion mechanism limits the $\mathrm{Ag}$ content in the body, it is likely that earthworms release $\mathrm{Ag}$ after biotransformation. Thus, soil organisms like earthworms might change the speciation of $\mathrm{Ag}$ in the environment and, consequently, its availability.

3D images of entire earthworms obtained by micro-CT showed that $\mathrm{Ag}$ (originating from $\mathrm{AgNPs}$ ) was stored and/or transiting in chloragogenous tissue, coelomocytes and the nephridial epithelium. A similar result was obtained by Diez-Ortiz et al. (2015b) by X-ray chemical analysis (micro-XRF) of the internal distribution in transverse sections: Ag was observed in the gut wall, liver-like chloragogenous tissue and nephridia. These cells and organs are related to immunity and detoxification functions. Chloragogenous tissue covers the outer part of the intestine and is considered to have a liver-like function. For instance, the chloragogenous tissue accumulates wastes produced by digestion and can sequester metals (Lapied et al., 2010; Morgan and Morgan, 1993; Vijver et al., 2004). Moreover, chloragogenous tissue plays a role in earthworm immunity (Fischer, 1993). Coelomocytes are immune cells involved in the elimination of foreign bodies by phagocytosis and encapsulation (Garcia-Velasco et al., 2017), and at least some coelomocytes are derived from chloragocytes (Hamed et al., 2002). Nephridia are organs involved in osmoregulation and excretion (Davidson et al., 2013).

In the present study, accumulation of $\mathrm{Ag}$ was concomitant with a decrease in $\mathrm{Cu}$ accumulation. $\mathrm{Cu}$ is an essential metal that is specifically stored by metallothioneins (MTs). MTs, stress proteins that bind essential and non-essential metals through thiolated bonds, participate in the homeostasis of essential metals such as $\mathrm{Zn}$ and $\mathrm{Cu}$ as well as non-essential metals such as $\mathrm{Cd}$ or mercury (Hg) (Demuynck et al., 2006; Vijver et al., 2004). Interestingly, in earthworms, MTs are preferentially but not exclusively localized in the epithelial cells of the intestine, chloragogenous tissue, coelomocytes and nephridia (Morgan et al., 2004). According to the localization of Ag observed by micro-CT, its internal speciation (linked to a thiolated molecule), and competition with $\mathrm{Cu}, \mathrm{Ag}$ is probably bound by MTs in earthworms. The same hypothesis was proposed by Baccaro et al. (2018), who also observed that bioaccumulated Ag was related to sulfur. Furthermore, in mice, Ag can bind to 
321 MT with higher affinity than Cu (Sugawara and Sugawara, 1984). Consequently, Ag probably displaces Cu from

322 MT. Moreover, Hayashi et al. (2013) and Curieses Silvana et al. (2017) observed changes in the expression of

323 genes encoding MTs in E. fetida exposed to $\mathrm{AgNPs}$ and $\mathrm{AgNO}_{3}$ (in natural and OECD soil, respectively).

324 Therefore, it seems that MTs have a role in the detoxification mechanisms of Ag. Taken together, these results

325 suggest a pathway for the absorption, detoxification and excretion of $\mathrm{Ag}$.

326 In summary, $\mathrm{Ag}$ is probably mainly taken up by ingestion, absorbed by the gut and at least temporarily

327 stored in chloragogenous tissue before detoxification. For excretion, Ag must be transferred from chloragocytes

328 to the nephridia. Two mechanisms can be proposed. First, MT-metal complexes are discharged from the

329 coelomic cavity and then excreted by the nephridia. This mechanism is supported by the work of Nordberg

330 (1989) and Morgan et al. (2004), who described the capacity of MTs linked to metals to enter excretory organs in

331 mammals and earthworms. Second, Ag could be transferred to coelomocytes in the coelomic cavity and stored,

332 inducing the gene encoding MTII (Brulle et al., 2008). Transfer of Ag into coelomocytes can occur via two

333 pathways: transformation of chloragocytes that have stored Ag into free coelomocyte cells or release of metal-

334 bound MT into the coelomic cavity by chloragocytes and subsequent uptake by coelomocytes. In the event of

335 excessive ingestion of Ag that can be not managed conventionally by storage in proteins and excretion, another

336 mechanism might help limit the levels of Ag in the body. For example, Roubalová et al. (2018) showed that

337 when earthworms are confronted by aggression, earthworms can expel coelomic fluid with coelomocytes via the dorsal pores. This mechanism would quickly remove from the body a large amount of metals trapped in the coelomocytes. 
Table 1: Silver content in the microcosms at the initial time point (mean in $\mathrm{mg} \mathrm{kg}^{-1}$ of dry matter). The results were obtained by ICP analysis. Standard deviations are in parentheses.

Figure 1: A. Mean percentage of weight loss of the earthworm groups in the microcosms between the beginning and end of the experiment. B. Mean percentage of earthworm survival in the microcosms between the beginning and end of the experiment. The concentrations $\mathrm{Cl}, \mathrm{C2}, \mathrm{C} 3$ and $\mathrm{C4}$ correspond to mean concentrations of $\mathrm{AgNO}_{3}$ and AgNPs of $33( \pm 16), 71( \pm 8), 117( \pm 11)$ and $277( \pm 24) \mathrm{mg} \mathrm{kg}^{-1}$ (dry matter) (the values were not significantly different between the two Ag sources). Asterisks (*) indicate statistically important differences between the Ag treatment and control. Lowercase letters in green indicate significant differences in biomass between the 4 doses of $\mathrm{Ag}$ (for one form of Ag). Lowercase letters in blue indicate significant differences in survival between the 4 doses of Ag (for one form of Ag). Uppercase letters in yellow indicate significant differences in biomass between the two forms of Ag (NPs or ionic), taking into account all concentrations. 'NA' indicates that biomass data were not available due to total mortality.

Figure 2: Ag content in earthworm bodies ( $\mathrm{mg} \mathrm{kg}^{-1}$ ). "AgNPs" corresponds to microcosms with silver nanoparticles. " $\mathrm{AgNO}_{3}$ " corresponds to microcosms with silver nitrate. The concentrations $\mathrm{Cl}, \mathrm{C} 2, \mathrm{C} 3$ and $\mathrm{C} 4$ correspond to $33( \pm 16), 71( \pm 8), 117( \pm 11)$ and $277( \pm 24) \mathrm{mg} \mathrm{kg}^{-1}$ (dry matter) (the mean concentrations of $\mathrm{AgNO}_{3}$ and $\mathrm{AgNPs}$ were not significantly different). Stars (*) indicate significant differences from the associated control without silver. Lowercase letters in orange indicate significant differences in metal content between the 4 concentrations (C1, C2, C3 and C4) of $\mathrm{Ag}$ (AgNPs and $\mathrm{AgNO}_{3}$ were not compared). Uppercase letters in yellow indicate significant differences in Ag content between the 2 forms of Ag (NPs or ionic), taking into account all concentrations. 'NA' indicates that data were not available due to significant mortality.

Figure 3: $\mathrm{Cu}$ contents in earthworm bodies $\left(\mathrm{mg} \mathrm{kg}^{-1}\right)$. "AgNPs" corresponds to microcosms with silver nanoparticles. " $\mathrm{AgNO}_{3}$ " corresponds to microcosms with silver nitrate. The concentrations $\mathrm{Cl}, \mathrm{C} 2, \mathrm{C} 3$ and $\mathrm{C} 4$ correspond to $33( \pm 16), 71( \pm 8), 117( \pm 11)$ and $277( \pm 24) \mathrm{mg} \mathrm{kg}^{-1}$ (dry matter) (mean concentrations of $\mathrm{AgNO}_{3}$ and $\mathrm{AgNPs}$, which were not significantly different). Stars (*) indicate significant differences from the associated control without Ag. Lowercase letters in purple indicate significant differences in metal contents among the 4 doses of $\mathrm{Ag}$ (for one form of $\mathrm{Ag}$ ). Uppercase letters in yellow indicate significant differences in $\mathrm{Cu}$ content between the 2 forms of Ag (NPs or ionic), taking into account all concentrations. Lowercase letters in 

indicates that data were not available due to significant mortality.

372

Figure 4: Examples of 2D orthoslices extracted from the reconstructed volume of (A) non-exposed earthworms (Dis-D3) and (B, C, D) exposed earthworms (AgNP-C3). The digestive tract (d), free cells in the coelomic cavity (coelomocytes) (c) and the nephridial epithelium ( $n)$ are indicated. The pixels colored in red in $(B, C, D)$ in dotted circles are brilliant voxels isolated by thresholding and associated with Ag. These brilliant pixels are not observed in (A). 1 px $=0.9 \mu m$.

Figure 5: A. Linear combination fitting (LCF) of the XANES spectra of the samples collected at different time points (dotted lines) and experimental spectra (solid lines) of soil and earthworms after 4 weeks of exposure to AgNPs and $\mathrm{AgNO}_{3}$. The curves for the samples are colored as follows: dark green, soil spiked with $\mathrm{AgNO}_{3}$; dark blue, soil spiked with AgNPs; light green, earthworms exposed to $\mathrm{AgNO}_{3}$; light blue, earthworms exposed to AgNPs. B. XANES spectra of the model compounds used for LCF. Ag-HA (in yellow) was used as a proxy for Ag complexed to natural organic matter (humic acids). AgNPs (in grey) corresponds to the initial NM300K AgNPs used for the experiment. Ag-thiol (in purple) was used as a proxy for Ag bound to an organic thiol. $\mathrm{Ag}_{2} S$ (in orange) corresponds to silver sulfide (acanthite mineral).

Sup. Inf. 1: Scheme of the experimental design. "Control" corresponds to the microcosm without any inputs. “AgNPs" corresponds to silver nanoparticles. "Dis" corresponds to dispersant. "AgNO ${ }_{3}$ " corresponds to silver nitrate. The concentrations C1, C2, C3 and C4 correspond to $33( \pm 16), 71( \pm 8), 117( \pm 11)$ and $277( \pm 24) \mathrm{mg}$ $\mathrm{kg}^{-1}$ of $\mathrm{Ag}$ (dry matter) (the mean concentrations of $\mathrm{AgNO}_{3}$ and $\mathrm{AgNPs}$ were not significantly different). The volumes D1, D2, D3 and D4 correspond to the volumes of dispersant added to the microcosms. Dispersant was added in the same amount as in the corresponding AgNPs microcosms, that is, 1.599, 2.666, 5.331 and 10.662 $m L$. 
Sup. Inf. 2: Metal contents in earthworms (mean in $\mathrm{mg} \mathrm{kg}^{-1}$ ). The results were obtained by ICP analysis.

"Control" corresponds to the microcosm without silver addition. "AgNPs" corresponds to silver nanoparticles.

"Dis" corresponds to dispersant. "AgNO 3 " corresponds to silver nitrate. The concentrations $\mathrm{Cl}, \mathrm{C} 2, \mathrm{C} 3$ and $\mathrm{C} 4$ correspond to $33( \pm 20), 71( \pm 10), 117( \pm 15)$ and $277( \pm 45) \mathrm{mg} \mathrm{kg}^{-1}$ (dry matter) (the mean concentrations of $\mathrm{AgNO}_{3}$ and $\mathrm{AgNPs}$ were not significantly different). Stars (*) indicate significant differences between the condition with Ag and the associated control without Ag. Standard deviations are in parentheses.

Sup. Inf. 3: 3D imaging of an earthworm by micro-CT. (top) Selection of FOV for high-resolution micro-CT thresholding step).

401

\begin{tabular}{|c|c|c|c|c|}
\hline Concentration & Control microcosms & Dispersant & AgNPs & AgNO $_{3}$ \\
\hline C1 (or D1) & & & & \\
\hline C2 (or D2) & \multirow{3}{*}{$1.95(1.23)$} & $0.69(0.97)$ & $26.33(10.63)$ & $39.53(20.66)$ \\
\cline { 1 - 4 } C3 (or D3) & & $0.61(1.06)$ & $70.50(8.15)$ & $71.03(8.71)$ \\
\cline { 1 - 4 } C4 (or D4) & & $0.18(0.31)$ & $109.57(8.05)$ & $124.30(7.59)$ \\
\cline { 3 - 5 } & & $0.00(0.00)$ & $262.93(27.87)$ & $290.90(10.81)$ \\
\hline
\end{tabular}
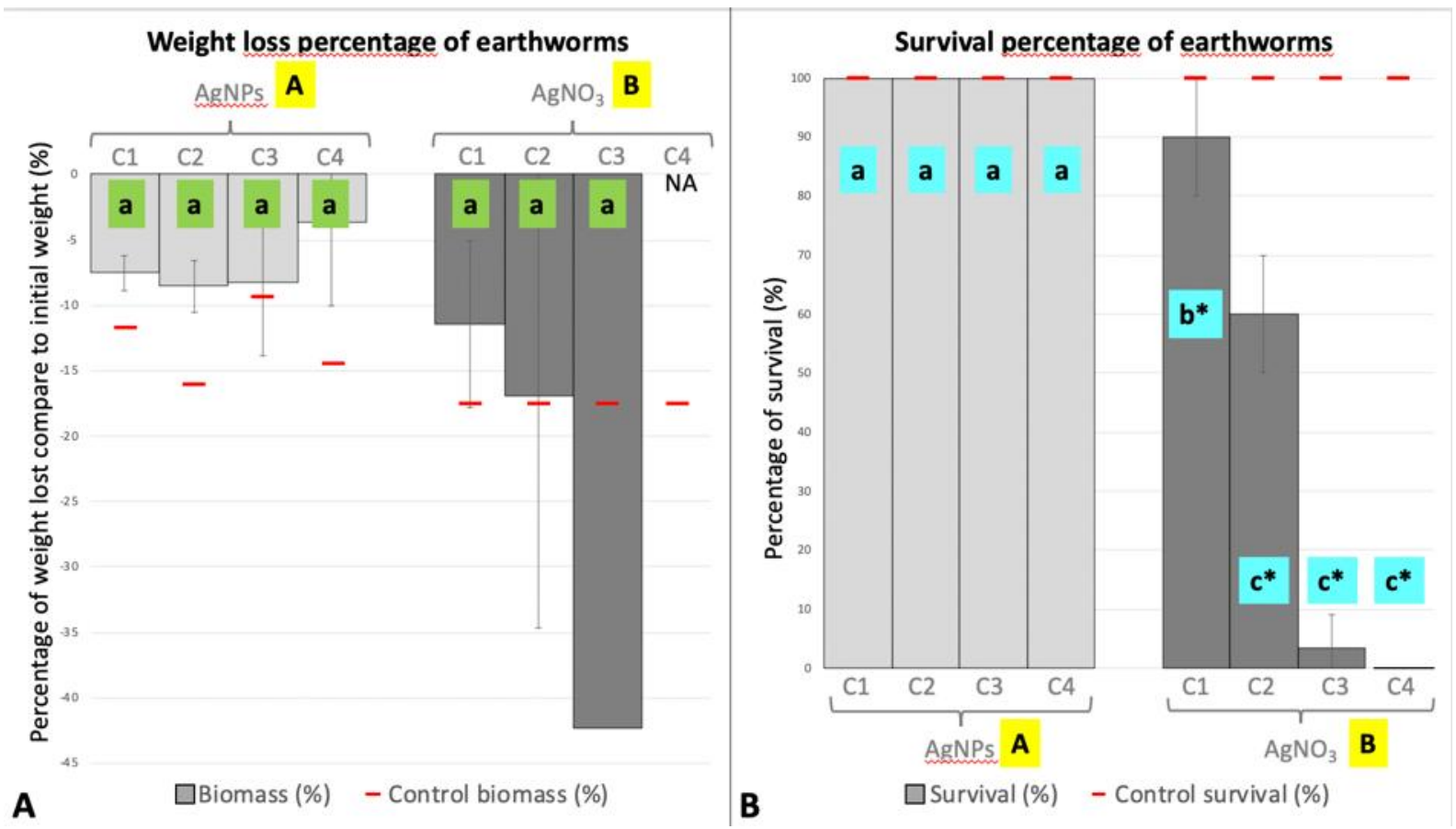


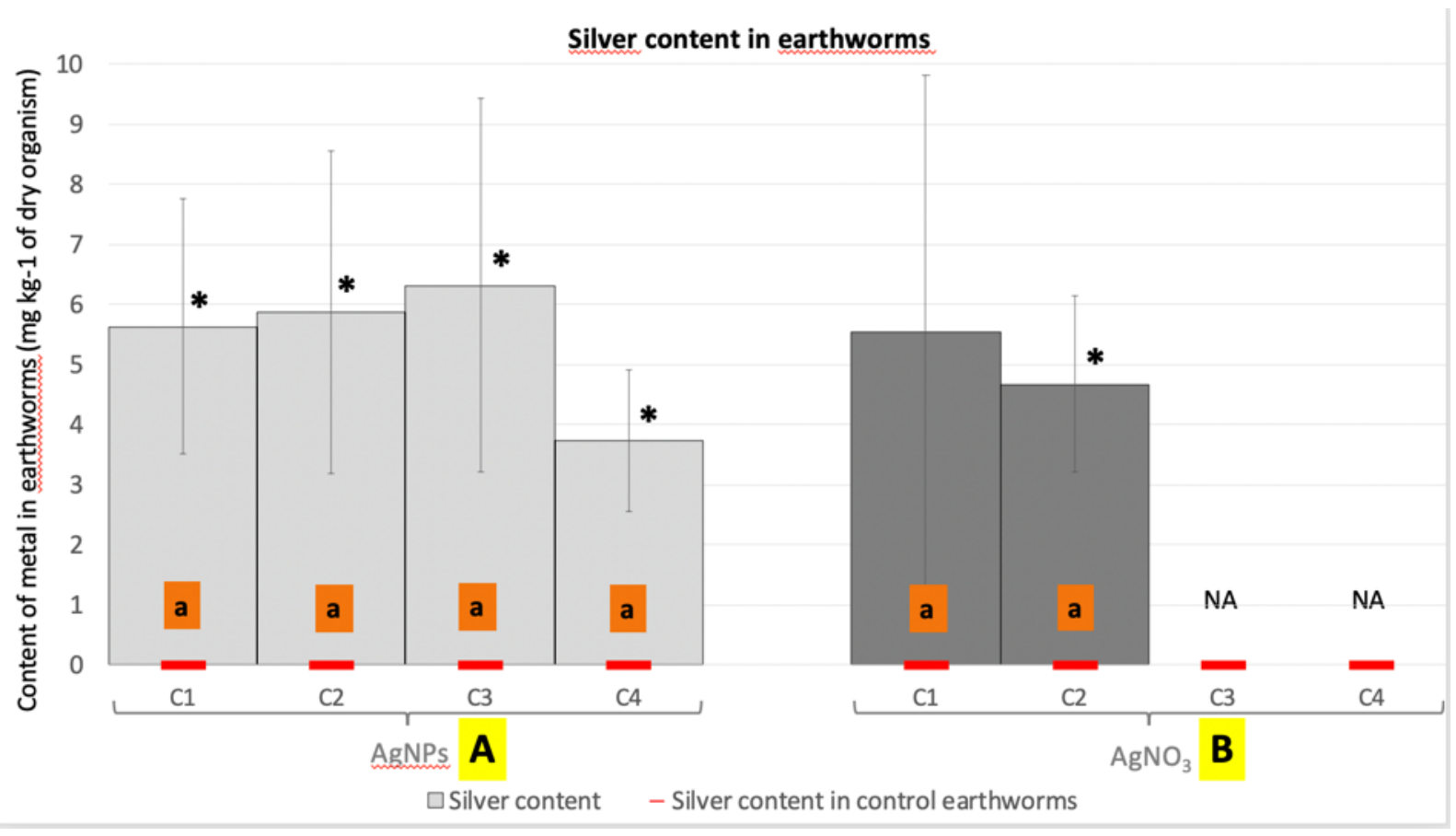

405

406

Copper content in earthworms

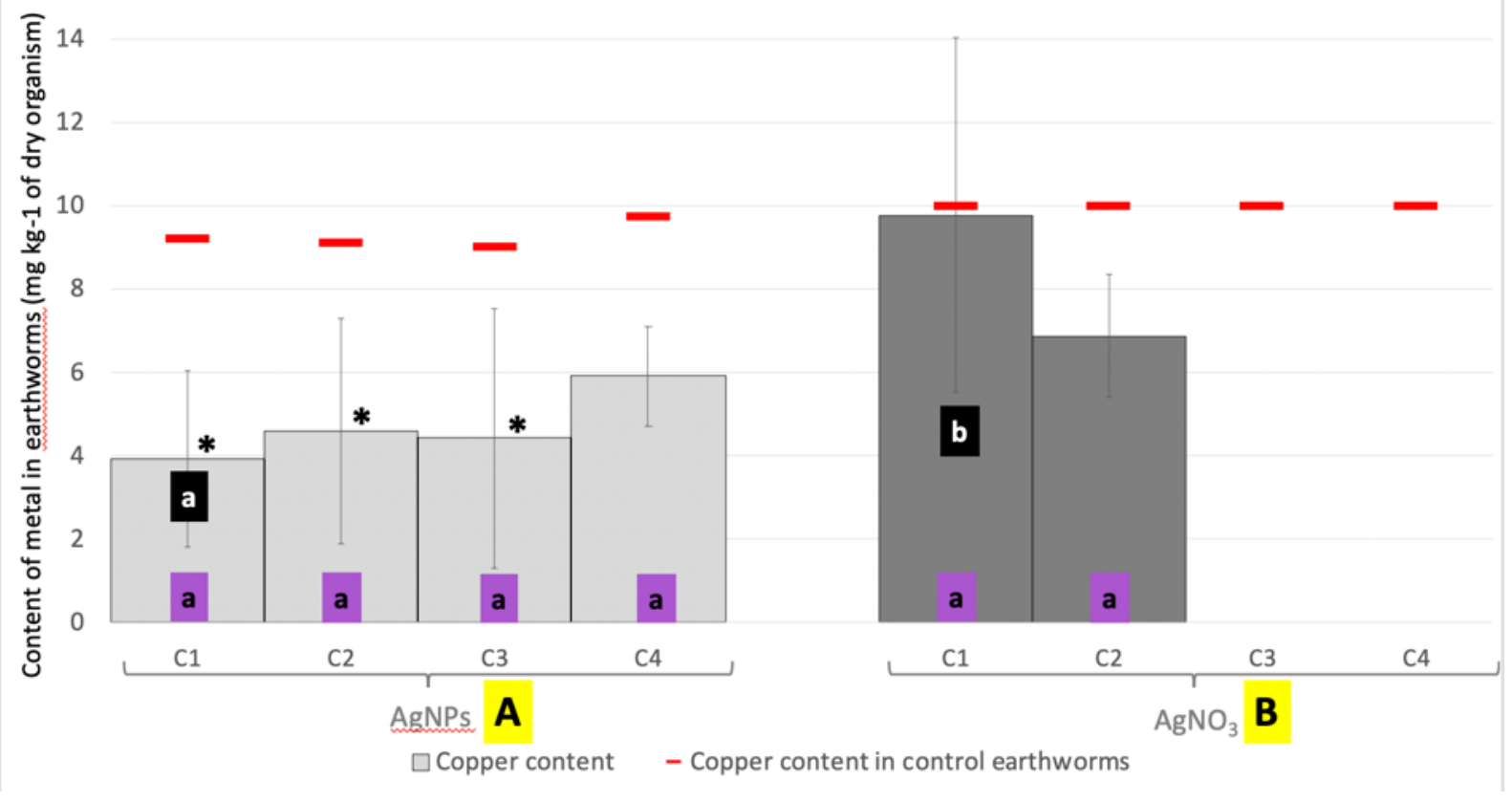




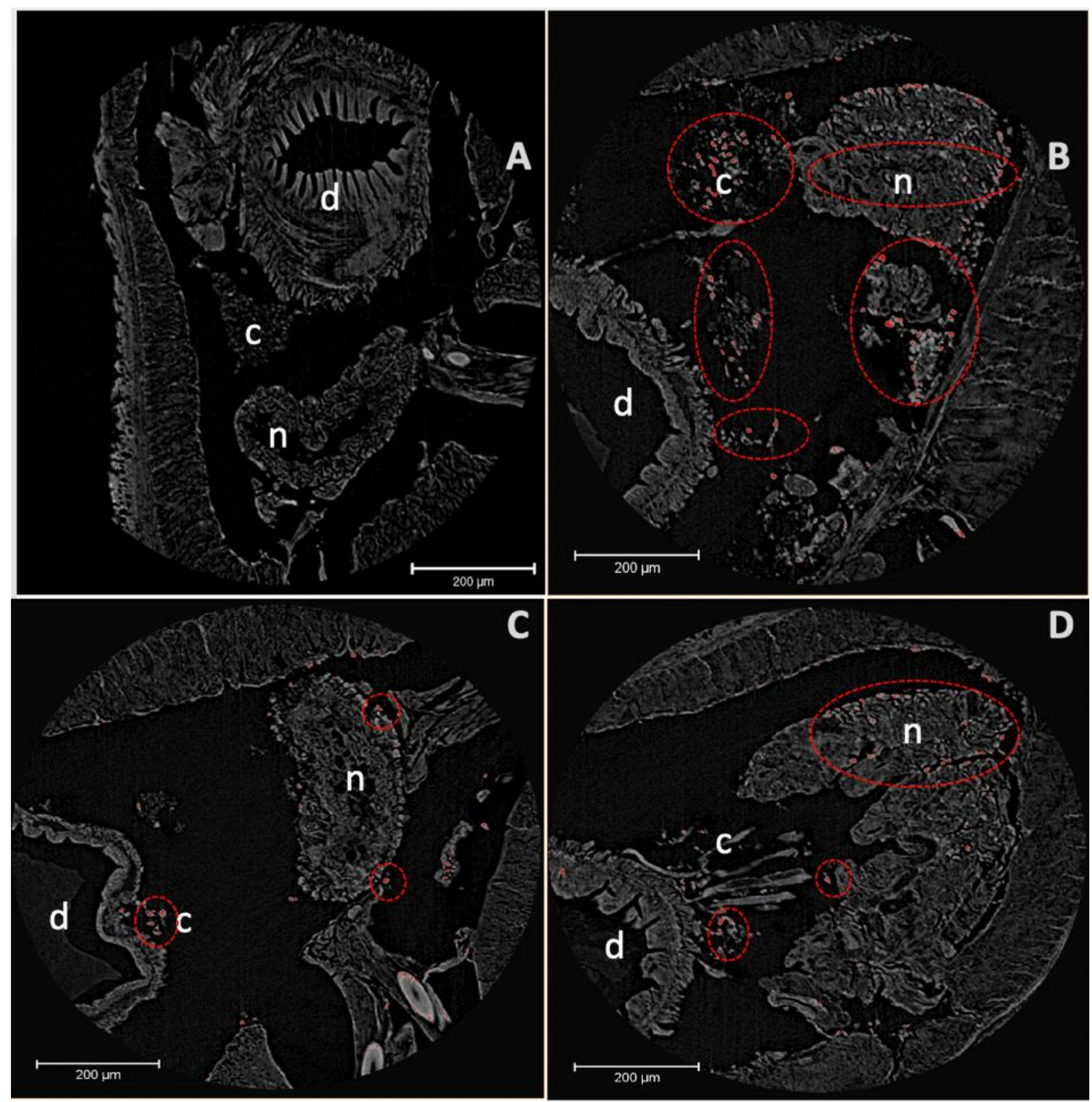




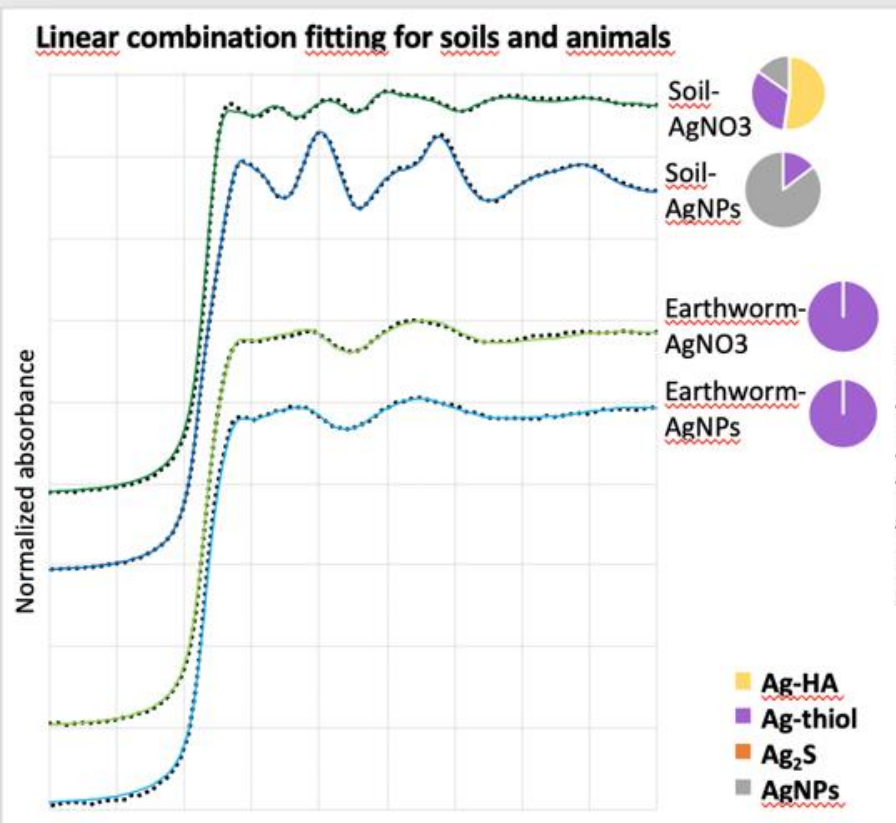

410

411
A.

Energy (eV)
Linear combination fitting for references

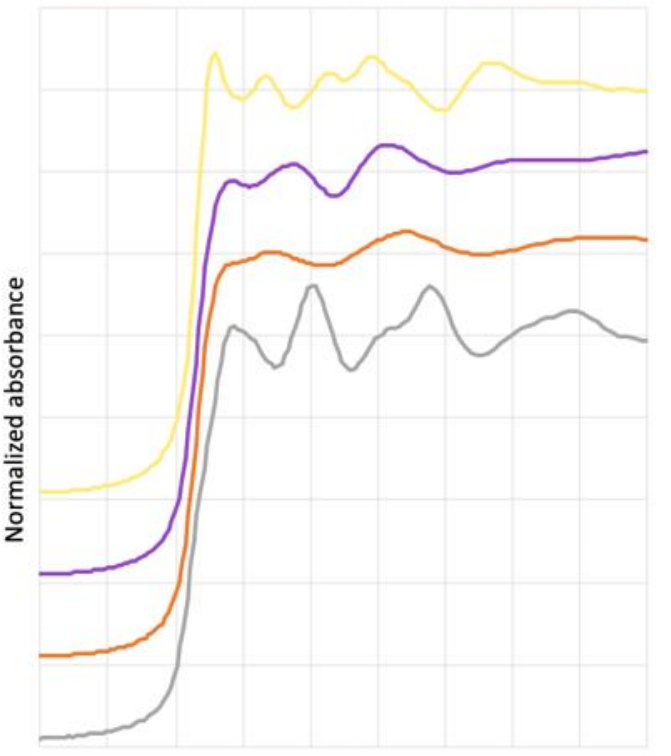

B.

Energy (eV)

$\begin{array}{llllllllll}25470 & 25490 & 25510 & 25530 & 25550 & 25570 & 25590 & 25610 & 25630 & 25650\end{array}$ 
Baccaro, M., Undas, A.K., de Vriendt, J., van den Berg, J.H.J., Peters, R.J.B., van den Brink, N.W., 2018. Ageing, dissolution and biogenic formation of nanoparticles: how do these factors affect the uptake kinetics of silver nanoparticles in earthworms? Environ. Sci. Nano 5, 1107-1116. https://doi.org/10.1039/C7EN01212H

Bernard, F., Brulle, F., Douay, F., Lemière, S., Demuynck, S., Vandenbulcke, F., 2010. Metallic trace element body burdens and gene expression analysis of biomarker candidates in Eisenia fetida, using an “exposure/depuration" experimental scheme with field soils. Ecotoxicol. Environ. Saf. 73, 1034-1045. https://doi.org/10.1016/j.ecoenv.2010.01.010

Bourdineaud, J.-P., Štambuk, A., Šrut, M., Radić Brkanac, S., Ivanković, D., Lisjak, D., Sauerborn Klobučar, R., Dragun, Z., Bačić, N., Klobučar, G.I.V., 2019. Gold and silver nanoparticles effects to the earthworm Eisenia fetida - the importance of tissue over soil concentrations. Drug Chem. Toxicol. 1-18. https://doi.org/10.1080/01480545.2019.1567757

Brulle, F., Cocquerelle, C., Wamalah, A.N., Morgan, A.J., Kille, P., Leprêtre, A., Vandenbulcke, F., 2008. cDNA cloning and expression analysis of Eisenia fetida (Annelida: Oligochaeta) phytochelatin synthase under cadmium exposure. Ecotoxicol. Environ. Saf. 71, 47-55. https://doi.org/10.1016/j.ecoenv.2007.10.032

Carbonell, G., Pro, J., Gómez, N., Babín, M.M., Fernández, C., Alonso, E., Tarazona, J.V., 2009. Sewage sludge applied to agricultural soil: Ecotoxicological effects on representative soil organisms. Ecotoxicol. Environ. Saf. 72, 1309-1319. https://doi.org/10.1016/j.ecoenv.2009.01.007

Chaurand, P., Liu, W., Borschneck, D., Levard, C., Auffan, M., Paul, E., Collin, B., Kieffer, I., Lanone, S., Rose, J., Perrin, J., 2018. Multi-scale X-ray computed tomography to detect and localize metal-based nanomaterials in lung tissues of in vivo exposed mice. Sci. Rep. 8, 1-11. https://doi.org/10.1038/s41598-018-21862-4

Chhipa, H., 2019. Applications of nanotechnology in agriculture. Methods Microbiol. 115-142.

Courtois, P., Rorat, A., Lemiere, S., Guyoneaud, R., Attard, E., Levard, C., Vandenbulcke, F., 2019. Ecotoxicology of silver nanoparticles and their derivatives introduced in soil with or without sewage sludge: A review of effects on microorganisms, plants and animals. Environ. Pollut. 253, 578-598. https://doi.org/10.1016/j.envpol.2019.07.053

Coutris, C., Hertel-Aas, T., Lapied, E., Joner, E.J., Oughton, D.H., 2011. Bioavailability of cobalt and silver nanoparticles to the earthworm Eisenia fetida. Nanotoxicology 6, 186-195. https://doi.org/10.3109/17435390.2011.569094

Curieses Silvana, P., García-Velasco, N., Urionabarrenetxea, E., Elena, S.M., Bilbao, E., Di Marzio Walter, D., Soto, M., 2017. Responses to silver nanoparticles and silver nitrate in a battery of biomarkers measured in coelomocytes and in target tissues of Eisenia fetida earthworms. Ecotoxicol. Environ. Saf. 141, 5763. https://doi.org/10.1016/j.ecoenv.2017.03.008

Davidson, S.K., Powell, R., James, S., 2013. A global survey of the bacteria within earthworm nephridia. Mol. Phylogenet. Evol. 67, 188-200. https://doi.org/10.1016/j.ympev.2012.12.005

Demuynck, S., Grumiaux, F., Mottier, V., Schikorski, D., Lemière, S., Leprêtre, A., 2006. Metallothionein response following cadmium exposure in the oligochaete Eisenia fetida. Comp. Biochem. Physiol. Toxicol. Pharmacol. CBP 144, 34-46. https://doi.org/10.1016/j.cbpc.2006.05.004

Diez-Ortiz, M., Lahive, E., George, S., Ter Schure, A., Van Gestel, C.A.M., Jurkschat, K., Svendsen, C., Spurgeon, D.J., 2015a. Short-term soil bioassays may not reveal the full toxicity potential for nanomaterials; bioavailability and toxicity of silver ions (AgNO3) and silver nanoparticles to earthworm Eisenia fetida in long-term aged soils. Environ. Pollut. 203, 191-198. https://doi.org/10.1016/j.envpol.2015.03.033

Diez-Ortiz, M., Lahive, E., Kille, P., Powell, K., Morgan, A.J., Jurkschat, K., Van Gestel, C.A.M., Mosselmans, J.F.W., Svendsen, C., Spurgeon, D.J., 2015b. Uptake routes and toxicokinetics of silver nanoparticles and silver ions in the earthworm Lumbricus rubellus. Environ. Toxicol. Chem. 34, 2263-2270. https://doi.org/10.1002/etc.3036

Fischer, E., 1993. The myelo-erythroid nature of the chloragogenous-like tissues of the annelids. Comp. Biochem. Physiol. A Physiol. 106, 449-453. https://doi.org/10.1016/0300-9629(93)90237-X

Garcia-Velasco, N., Gandariasbeitia, M., Irizar, A., Soto, M., 2016. Uptake route and resulting toxicity of silver nanoparticles in Eisenia fetida earthworm exposed through Standard OECD Tests. Ecotoxicology 25, 1543-1555. https://doi.org/10.1007/s10646-016-1710-2

Garcia-Velasco, N., Peña-Cearra, A., Bilbao, E., Zaldibar, B., Soto, M., 2017. Integrative assessment of the effects produced by $\mathrm{Ag}$ nanoparticles at different levels of biological complexity in Eisenia fetida maintained in two standard soils (OECD and LUFA 2.3). Chemosphere 181, 747-758. https://doi.org/10.1016/j.chemosphere.2017.04.143 
Gomes, S.I.L., Hansen, D., Scott-Fordsmand, J.J., Amorim, M.J.B., 2015. Effects of silver nanoparticles to soil invertebrates: Oxidative stress biomarkers in Eisenia fetida. Environ. Pollut. 199, 49-55. https://doi.org/10.1016/j.envpol.2015.01.012

Hamed, S.S., Kauschke, E., Cooper, E.L., 2002. Cytochemical Properties of Earthworm Coelomocytes Enriched by Percoll, in: A New Model for Analyzing Antimicrobial Peptides with Biomedical Applications., NATO Science Series. https://doi.org/10.3923/ijzr.2005.74.83

Hayashi, Y., Heckmann, L.-H., Simonsen, V., Scott-Fordsmand, J.J., 2013. Time-course profiling of molecular stress responses to silver nanoparticles in the earthworm Eisenia fetida. Ecotoxicol. Environ. Saf. 98, 219-226. https://doi.org/10.1016/j.ecoenv.2013.08.017

Heckmann, L.-H., Hovgaard, M.B., Sutherland, D.S., Autrup, H., Besenbacher, F., Scott-Fordsmand, J.J., 2011. Limit-test toxicity screening of selected inorganic nanoparticles to the earthworm Eisenia fetida. Ecotoxicology 20, 226-233. https://doi.org/10.1007/s10646-010-0574-0

Homa, J., Rorat, A., Kruk, J., Cocquerelle, C., Plytycz, B., Vandenbulcke, F., 2015. Dermal exposure of Eisenia andrei earthworms: Effects of heavy metals on metallothionein and phytochelatin synthase gene expressions in coelomocytes. Environ. Toxicol. Chem. 34, 1397-1404. https://doi.org/10.1002/etc.2944

Kaegi, R., Voegelin, A., Ort, C., Sinnet, B., Thalmann, B., Krismer, J., Hagendorfer, H., Elumelu, M., Mueller, E., 2013. Fate and transformation of silver nanoparticles in urban wastewater systems. Water Res. 47, 3866-3877. https://doi.org/10.1016/j.watres.2012.11.060

Kaegi, R., Voegelin, A., Sinnet, B., Zuleeg, S., Hagendorfer, H., Burkhardt, M., Siegrist, H., 2011. Behavior of Metallic Silver Nanoparticles in a Pilot Wastewater Treatment Plant. Environ. Sci. Technol. 45, 39023908. https://doi.org/10.1021/es1041892

Khan, M.R., Rizvi, T.F., 2017. Application of Nanofertilizer and Nanopesticides for Improvements in Crop Production and Protection, in: Ghorbanpour, M., Manika, K., Varma, A. (Eds.), Nanoscience and PlantSoil Systems, Soil Biology. Springer International Publishing, Cham, pp. 405-427. https://doi.org/10.1007/978-3-319-46835-8_15

Klein, C.L., Stahlmecke, B., Romazanov, J., Kuhlbusch, T.A.J., Van Doren, E., De Temmerman, P.-J., Mast, J., Wick, P., Krug, H., Locoro, G., Hund-Rinke, K., Kördel, W., Friedrichs, S., Maier, G., Werner, J., Linsinger, T., Gawlik, B.M., Comero, S., Institute for Health and Consumer Protection, European Commission, Joint Research Centre, Institute for Environment and Sustainability, Institute for Reference Materials and Measurements, 2011. NM-Series of representative manufactured nanomaterials: NM-300 silver characterisation, stability, homogeneity. Publications Office, Luxembourg.

Lapied, E., Moudilou, E., Exbrayat, J.-M., Oughton, D.H., Joner, E.J., 2010. Silver nanoparticle exposure causes apoptotic response in the earthworm Lumbricus terrestris (Oligochaeta). Nanomed. 5, 975-984. https://doi.org/10.2217/nnm.10.58

Levard, C., Hotze, E.M., Lowry, G.V., Brown, G.E., 2012. Environmental Transformations of Silver Nanoparticles: Impact on Stability and Toxicity. Environ. Sci. Technol. 46, 6900-6914. https://doi.org/10.1021/es2037405

Ma, R., Levard, C., Judy, J.D., Unrine, J.M., Durenkamp, M., Martin, B., Jefferson, B., Lowry, G.V., 2014. Fate of Zinc Oxide and Silver Nanoparticles in a Pilot Wastewater Treatment Plant and in Processed Biosolids. Environ. Sci. Technol. 48, 104-112. https://doi.org/10.1021/es403646x

McGillicuddy, E., Murray, I., Kavanagh, S., Morrison, L., Fogarty, A., Cormican, M., Dockery, P., Prendergast, M., Rowan, N., Morris, D., 2017. Silver nanoparticles in the environment: Sources, detection and ecotoxicology. Sci. Total Environ. 575, 231-246. https://doi.org/10.1016/j.scitotenv.2016.10.041

Mendes, L.A., Maria, V.L., Scott-Fordsmand, J.J., Amorim, M.J.B., 2015. Ag Nanoparticles (Ag NM300K) in the Terrestrial Environment: Effects at Population and Cellular Level in Folsomia candida (Collembola). Int. J. Environ. Res. Public. Health 12, 12530-12542. https://doi.org/10.3390/ijerph121012530

Morgan, A.J., Stürzenbaum, S.R., Winters, C., Grime, G.W., Aziz, N.A.A., Kille, P., 2004. Differential metallothionein expression in earthworm (Lumbricus rubellus) tissues. Ecotoxicol. Environ. Saf. 57, 11-19. https://doi.org/10.1016/j.ecoenv.2003.08.022

Morgan, J.E., Morgan, A.J., 1993. Seasonal changes in the tissue-metal (Cd, Zn and Pb) concentrations in two ecophysiologically dissimilar earthworm species: pollution-monitoring implications. Environ. Pollut. 82, 1-7. https://doi.org/10.1016/0269-7491(93)90155-H

Nordberg, G.F., 1989. Modulation of metal toxicity by metallothionein. Biol. Trace Elem. Res. $21,131$. https://doi.org/10.1007/BF02917245

Novo, M., Lahive, E., Díez-Ortiz, M., Matzke, M., Morgan, A.J., Spurgeon, D.J., Svendsen, C., Kille, P., 2015. Different routes, same pathways: Molecular mechanisms under silver ion and nanoparticle exposures in the soil sentinel Eisenia fetida. Environ. Pollut. 205, 385-393. https://doi.org/10.1016/j.envpol.2015.07.010 
OCDE, 1984. Ver de terre, essai de toxicité aigüe, Ligne directrice $\mathrm{N}^{\circ} 207$, Ligne directrice de l'OCDE pour les essais de produits chimiques, OCDE, Paris.

Pradas del Real, A.E., Vidal, V., Carrière, M., Castillo-Michel, H., Levard, C., Chaurand, P., Sarret, G., 2017. Silver Nanoparticles and Wheat Roots: A Complex Interplay. Environ. Sci. Technol. 51, 5774-5782. https://doi.org/10.1021/acs.est.7b00422

Proux, O., Biquard, X., Lahera, E., Menthonnex, J.-J., Prat, A., Ulrich, O., Soldo, Y., Trévisson, P., Kapoujyan, G., Perroux, G., Taunier, P., Grand, D., Jeantet, P., Deléglise, M., Roux, J.-P., Hazemann, J.-L., 2005. FAME : A new beamline for X-ray absorption investigations of very-diluted systems of environmental, material and biological interests. Phys. Scr. 115, 970-973. https://doi.org/10.1238/Physica.Topical.115a00970

R Core Team, 2008. R: A language and environment for statistical computing. R Foundation for Statistical Computing, Vienna, Austria. URL https://www.R-project.org/

Ravel, B., Newville, M., 2005. ATHENA, ARTEMIS, HEPHAESTUS: data analysis for X-ray absorption spectroscopy using IFEFFIT. J. Synchrotron Radiat. 12, 537-541. https://doi.org/10.1107/S0909049505012719

Roubalová, R., Płytycz, B., Procházková, P., Navarro Pacheco, N.I., Bilej, M., 2018. Annelida: Environmental Interactions and Ecotoxicity in Relation to the Earthworm Immune System, in: Cooper, E.L. (Ed.), Advances in Comparative Immunology. Springer International Publishing, Cham, pp. 933-951. https://doi.org/10.1007/978-3-319-76768-0_27

Shoults-Wilson, W.A., Reinsch, B.C., Tsyusko, O.V., Bertsch, P.M., Lowry, G.V., Unrine, J.M., 2010. Effect of silver nanoparticle surface coating on bioaccumulation and reproductive toxicity in earthworms ( Eisenia fetida ). Nanotoxicology 5, 432-444. https://doi.org/10.3109/17435390.2010.537382

Sugawara, N., Sugawara, C., 1984. Comparative study of effect of acute administration of cadmium and silver on ceruloplasmin and metallothionein: Involvement of disposition of copper, iron, and zinc. Environ. Res. 35, 507-515. https://doi.org/10.1016/0013-9351(84)90157-9

Unrine, J., Bertsch, P., Hunyadi, S., 2008. Bioavailability, Trophic Transfer, and Toxicity of Manufactured Metal and Metal Oxide Nanoparticles in Terrestrial Environments, in: Nanoscience and Nanotechnology. John Wiley \& Sons, Ltd, pp. 345-366. https://doi.org/10.1002/9780470396612.ch14

Usman, K., Khan, S., Ghulam, S., Khan, M.U., Khan, N., Khan, M.A., Khalil, S.K., 2012. Sewage Sludge: An Important Biological Resource for Sustainable Agriculture and Its Environmental Implications. Am. J. Plant Sci. 03, 1708-1721. https://doi.org/10.4236/ajps.2012.312209

Vance, M.E., Kuiken, T., Vejerano, E.P., McGinnis, S.P., Hochella, M.F., Rejeski, D., Hull, M.S., 2015. Nanotechnology in the real world: Redeveloping the nanomaterial consumer products inventory. Beilstein J. Nanotechnol. 6, 1769-1780. https://doi.org/10.3762/bjnano.6.181

Vijver, M.G., Van Gestel, C.A.M., Lanno, R.P., Van Straalen, N.M., Peijnenburg, W.J.G.M., 2004. Internal metal sequestration and its ecotoxicological relevance: a review. Environ. Sci. Technol. 38, 4705-4712. https://doi.org/10.1021/es040354g

Vijver, M.G., Vink, J.P.M., Miermans, C.J.H., van Gestel, C.A.M., 2003. Oral sealing using glue: a new method to distinguish between intestinal and dermal uptake of metals in earthworms. Soil Biol. Biochem. 35, 125-132. https://doi.org/10.1016/S0038-0717(02)00245-6

Yan, A., Chen, Z., 2019. Impacts of Silver Nanoparticles on Plants: A Focus on the Phytotoxicity and Underlying Mechanism. Int. J. Mol. Sci. 20, 1003. https://doi.org/10.3390/ijms20051003

Yu, S., Yin, Y., Liu, J., 2013. Silver nanoparticles in the environment. Env. Sci Process. Impacts 15, 78-92. https://doi.org/10.1039/C2EM30595J 